\title{
An Investigation into the Electrochemical Behavior of Beta-Blocker Drugs Using Reduced Graphene Oxide Modified Screen Printed Electrodes
}

\author{
Hilal ÇELİK KAZICI*
}

Van Yüzüncü Yıl University, Faculty of Engineering, Department of Chemical Engineering, Van

(ORCID: 0000-0001-6391-1811)

\begin{abstract}
In this study, the electrochemical behavior of propranolol was investigated on screen printed electrodes (SPCE) with reduced graphene oxide (rGO). Oxidation process, cyclic voltammetry (CV) and differential pulse voltammetry (DPV) techniques were conducted by using measurements. The results showed that rGO increased the oxidation rate by increasing the peak current, and therefore oxidizing these drugs at appropriate potentials. The modified SPCE exhibited excellent catalytic activity towards oxidation of the beta-blockers at an unusually positive potential in phosphate buffer solution (PBS). The linear concentration range and the detection limit of the proposed sensor for the detection of propranolol was 5- $50 \mu \mathrm{M}$ and $2.61 \mu \mathrm{M}$, respectively.
\end{abstract}

Keywords: Beta-blocker, Reduced graphene oxide, Screen printed electrode.

\section{İndirgenmiş Grafen Oksit Modifiye Yüzey Baskılı Karbon Elektrotlar Kullanılarak Beta-Bloker İlaçların Elektrokimyasal Davranışının Araştırılması}

\begin{abstract}
$\ddot{\mathbf{O} z}$
$\mathrm{Bu}$ çalışmada, propranololün elektrokimyasal davranışı, indirgenmiş grafen oksit (rGO) ile modifiye edilmiş yüzey baskılı karbon elektrotlar (SPCE) ile incelenmiştir. Oksidasyon işlemi, döngüsel voltametri (CV) ve diferansiyel puls voltametri (DPV) teknikleri kullanılarak gerçekleştirilmiştir. Sonuçlar, rGO'nun oksidasyon pik akımını artırarak bu ilaçları uygun potansiyellerde oksitlediğini göstermiştir. Modifiye edilmiş SPCE, beta-blokerlerin, fosfat tampon çözeltisinde (PBS) alışılmadık derecede pozitif bir potansiyelde oksidasyonuna doğru mükemmel katalitik aktivite sergilemiştir. Propranololün tespiti için önerilen sensörün doğrusal konsantrasyon aralığ1 ve tespit limiti, sırasıyla, $50 \mu \mathrm{M}$ ve $2.61 \mu \mathrm{M}$ olarak elde edilmiştir.
\end{abstract}

Anahtar kelimeler: Beta-bloker, İndirgenmiş grafen oksit, Yüzey baskılı elektrot.

\section{Introduction}

The action mechanism of beta-blockers on the sympathetic nervous system is based on the binding of the $\beta 1$ and $\beta 2$ receptors and inhibiting the effects of norepinephrine and epinephrine [1]. These substances are used in the treatment of hypertension, cardiac arrhythmias and angina pectoris [2]. There are two types of beta-blockers, which are generally used in the treatment of hypertension. These are selective beta-blockers $(\beta 1)$ such as atenolol, betaxolol, bisoprolol, metoprolol, nevibolol and nonselective beta-blockers $(\beta 1, \beta 2)$ such as propranolol, carteolol, penbutolol, pindolol, timolol.

Carvedilol is a $\alpha 1$ and $\beta 1$ beta blocker [3]. Propranolol is the first beta blocker to be used in the clinical treatment of angina pectoris. The active substance of this drug reduces blood pressure in all vessel beds except for the brain vessels, reduces blood pressure and controls cardiac arrhythmia. It also

"Corresponding author: hilalkazici@yyu.edu.tr

Received: 26.04.2019, Accepted: 11.07.2019 
decreases the volume of breath in the bronchi and bronchioles by blocking the $\beta 2$ receptors. Another important action mechanism of propranolol is that it controls anxiety and stress somatic symptoms [4]. Due to the widespread use of blockers, it has become increasingly important to detect the reliability of these drugs accurately. For this purpose, a variety of methods such as spectrophotometry [5], gas chromatography [6], capillary electrophoresis [7] and high performance liquid chromatography [8] have been developed. In contrast to these methods, electrochemical methods have taken an important place in the literature as being more suitable for the detection of drugs due to their low cost as well as their high degree of sensitivity. Electrochemical methods are the most suitable methods for investigating the redox behavior of drugs and other substance [9-11]. The most striking feature of modern electroanalytical methods is that they are not affected by any materials that can interfere. Therefore, the samples can be prepared simply by dissolving the pharmaceutical component in a suitable solvent.

In a study on the determination of propranolol electrochemically, the surface was modified with copper oxide using carbon paste electrode [9]. The linear concentration range started from $10 \mu \mathrm{M}$. It is clear that concentrations below $10 \mu \mathrm{M}$ cannot be measured accurately. However, in this study a very good linear concentration of $5-50 \mu \mathrm{M}$ was obtained. Although the detection limits are very close to the two studies.

In this study, the redox behavior of antihypertensive drugs such as carvedilol and metoprolol were investigated, however a detailed electro-catalytic study was carried out on propranolol. For this purpose, a screen printed electrode (SPCE) system modified with reduced graphene oxide (rGO) was developed to ensure that propranolol can be examined in a fast, reliable and reproducible manner with redox behavior thanks to voltammetric methods. A rapid and simple method with in situ monitoring was developed without complex sample pre-treatments with SPCE. In recent years, graphene based materials have caught great attention in various applications including catalyst and electrocatalysts because of their superior electrical conductivity and load mobility. Therefore in this study, the SPCE surface was modified with rGO. A single-use, cost-effective electrocatalytic method was developed with rGO for the investigation of the electrochemical behavior of propranolol.

\section{Experimental}

\subsection{Chemicals and reagents}

Potassium dihydrogen phosphate $\left(\mathrm{KH}_{2} \mathrm{PO}_{4}\right)$, potassium hydrogen phosphate $\left(\mathrm{K}_{2} \mathrm{HPO}_{4}\right)$, potassium chloride $(\mathrm{KCl})$ and sodium hydroxide $(\mathrm{NaOH})$ were obtained from Merck. rGO (15-20 sheets, 4-10\% edge-oxidized), propranolol, carvedilol, metoprolol and nafion (5\% w/v) were obtained from SigmaAldrich.

Electrochemical measurements were performed with the help of Bio-Logic SP50 model potentiostat. SPCE (Working electrode: $\mathrm{C}(4 \mathrm{~mm})$, Auxiliary electrode: $\mathrm{C}$ and Reference electrode: $\mathrm{Ag}$ / $\mathrm{AgCl}(0.1 \mathrm{M} \mathrm{KCl}))$ were obtained from Dropsens. A calibrated Mettler Toledo $\mathrm{pH}$-meter was used to prepare the buffer at the desired $\mathrm{pH}$ at room temperature. The mixing process at the desired rate for solution dispersion was carried out with Isolab model magnetic stirrer. TEM TPG 320 model $0.001 \mathrm{mg}$ sensitive electronic balance was used for weighing the solid chemicals. The ultra-pure water used in the experiments was obtained from the Millipore Milli-Q Direct Q-3 ultra-pure water device.

\subsection{Cleaning and activation of electrode surface}

In order to obtain optimum electrochemical performance of SPCE, mild electrochemical activation is required [12]. The cleaning and activation of the electrode surface lead to an increase in the current of electrochemical measurements, a reduction in the signal-to-noise ratio and a reduction of irreversible reactions. The electrochemical pretreatment for the activation of the electrode surface was carried out in a buffered buffer of $0.1 \mathrm{M} \mathrm{pH} \mathrm{8}$, at a scanning speed of $50 \mathrm{mVs}^{-1}$ and by applying cyclic voltammetry at a potential range of -0.5 to $+0.7 \mathrm{~V}$ [13]. Before using the electrodes, the surface was cleaned and activated, washed with ultra-pure water and dried with high purity nitrogen $\left(\mathrm{N}_{2}\right)$ gas. 


\subsection{Preparation of standard and support electrolyte solution}

Propranolol, carvedilol and metoprolol were dissolved in ethanol. A $0.1 \mathrm{M}$ stock solution was prepared by weighing $0.75 \mathrm{mg}$ of propranolol which was dissolved with ethanol at a total volume of $25 \mathrm{~mL} .1 \mathrm{mg}$ of carvedilol and $0.2 \mathrm{mg}$ of metoprolol were carefully weighed and dissolved in ethanol to complete the total volume to $25 \mathrm{~mL}$. Standard substances in different concentrations were prepared by diluting the support electrolytes from stock solutions.

In the experiments, $0.2 \mathrm{M}$ phosphate buffer solution (PBS) prepared using $\mathrm{KH}_{2} \mathrm{PO}_{4}$ and $\mathrm{K}_{2} \mathrm{HPO}_{4}$ in $0.1 \mathrm{M} \mathrm{KCl}$ was used as a support electrolyte. During the preparation of the support electrolyte, $\mathrm{pH}$ adjustment was made by adding $1 \mathrm{M} \mathrm{NaOH}$ or $1 \mathrm{M} \mathrm{HCl}$. All solutions used in the experiments were prepared in phosphate buffer system.

\subsection{Modification of screen printed electrodes with rGO}

For the modification of SPCE, $3 \mu \mathrm{L}$ of the rGO solution was drop-casted onto the working electrode surface. Electrode was kept in the dark at room temperature until it was dry [14]. It was then cleaned in ultrapure water for 15 minutes with a magnetic stirrer and dried with high purity $\mathrm{N}_{2}$ gas.

\subsection{Electrochemical measurements}

Electrochemical measurements were performed using electrochemical techniques such as cyclic voltammetry (CV) and differential pulse voltammetry (DPV). As a result of using the CV techniques, the nature of the electrochemical reactions was revealed in a short time. In CV, the current-potential change is usually in the form of a peak. The effect of the scan rate was monitored in the studied potential range. The relation between peak height and scanning speed gives information about the mechanism of adsorption, diffusion or kinetics.

In DPV, pulses with constant amplitude were applied to the increased direct current potential in normal voltammetry. The current was measured before and after the pulse. The difference between the currents was plotted against the potential and the height of the peak was directly proportional to the concentration of the analyte. Therefore, this technique can be used for qualitative analysis.

\section{Results and Discussion}

\subsection{Electrochemical behavior of beta blockers on the SPCE}

Voltammetric behavior of propranolol is shown in Figure 1 using a bare SPCE and modified SPCE with rGO in pH 7.0 and 0.1 M PBS. On the bare electrode surface, no significant peak of propranolol was observed. It is clear that the current is very low in the voltamogram which shows that the determination of propranolol by a bare electrode system is not possible. However, a high-current oxidation peak of about $0.7 \mathrm{~V}(750 \mu \mathrm{A})$ around $0.5 \mathrm{~V}$ was obtained for propranolol on the $\mathrm{rGO} / \mathrm{SPCE}$ surface.

After the determination of the working electrode type, the electrochemical behaviors on the surface of the rGO/SPCE were investigated using carvedilol and metoprolol (Figure 2). For this purpose, $\mathrm{CV}$ measurements of $1 \mathrm{M}$ propranolol, carvedilol and metoprolol solution in $0.1 \mathrm{M} \mathrm{PBS}$ with a $\mathrm{pH}$ of 7.0 were carried out.

It was observed that propranolol provided the best peak current from the beta blockers prepared under the same conditions (Figure 3). The oxidation process on the rGO/SPCE surface showed a high electrocatalytic effect for propranolol. Therefore, an effective method for selective oxidation of betablocker drugs was developed. The oxidation mechanism for the beta-blocker drug studied is presented in Figure 3. 


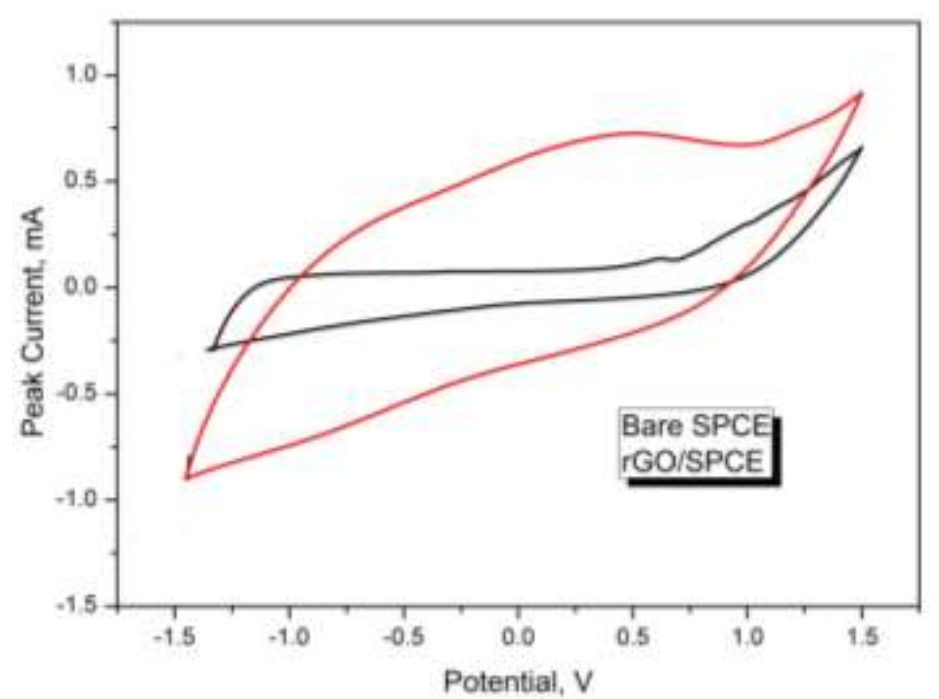

Figure 1. CV of $1 \mathrm{mM}$ propranolol on bare electrode and rGO modified surfaces, support electrolyte: $0.1 \mathrm{M}$ PBS, pH 7.0, scan rate $50 \mathrm{mV} \mathrm{s}^{-1}$

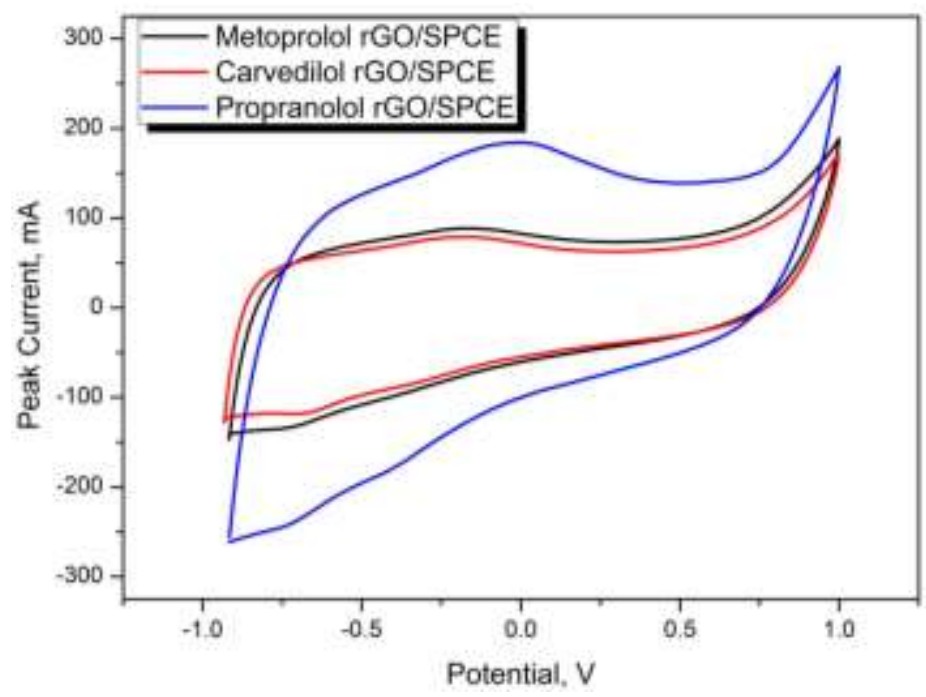

Figure 2. CV on $0.5 \mathrm{mM}$ propranolol, metoprolol and carvedilol rGO/SPCE modified surfaces, support electrolyte: $0.1 \mathrm{M}$ PBS, $\mathrm{pH} 7.0$, scan rate $50 \mathrm{mV} \mathrm{s}^{-1}$

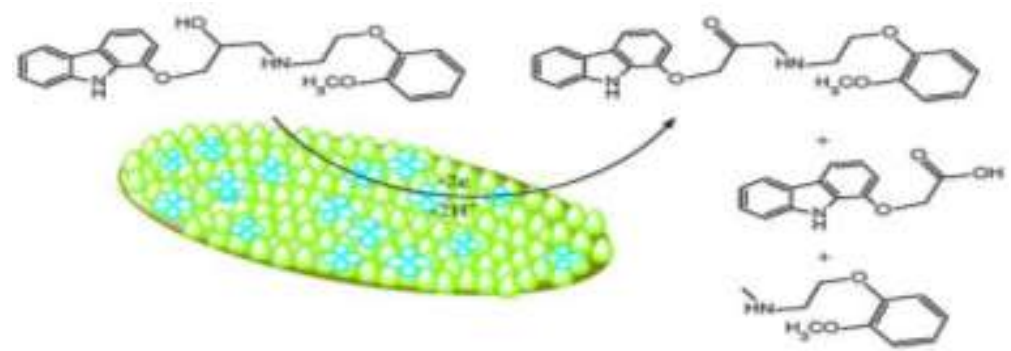

Figure 3. Oxidation mechanism of propranolol

When the current passes through the interface between the solution and the electrode, oxidation occurs in one of the electrodes and the reduction reaction occurs, and these reactions are referred to as Faraday laws [15]. Figure 4 illustrates the most appropriate potential for the transfer of electrons between the electrode and the solution interface. As can be seen from the figure, when the $1.5 \mathrm{~V}$ potential was applied, the highest $(500 \mu \mathrm{A})$ oxidation peak current was obtained. 


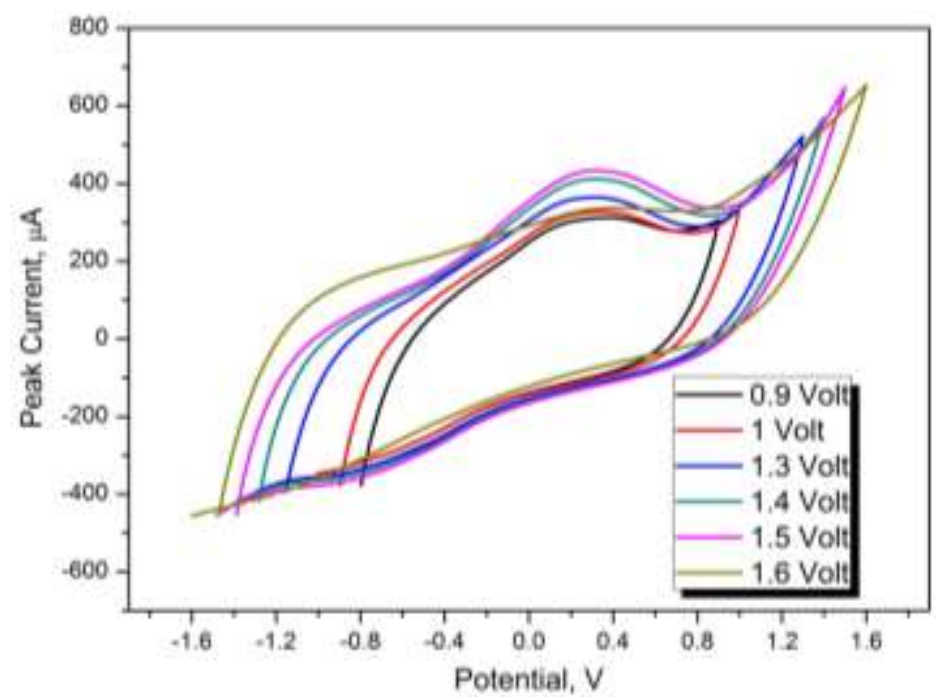

Figure 4. Propranolol CV of optimal working potential on rGO/SPCE modified surfaces: $1 \mathrm{mM}$ propranolol, support electrolyte $0.1 \mathrm{M}$ PBS, $\mathrm{pH} 7.0$, scan rate $50 \mathrm{mVs}^{-1}$

The CVs of propranolol in PBS ranging from $\mathrm{pH} 5.0$ to 10.0 in $1 \mathrm{mM}$ concentration are shown in Figure 5. As can be seen from the voltamograms, while no oxidation peaks were observed at $\mathrm{pH} 5.0$ or 10.0, peaks were observed at $\mathrm{pH} 7.0$ and 8.0 at about $+0.5 \mathrm{~V}$. According to the results of the $\mathrm{pH}$ scan of propranolol, it was observed that the current response was high in the PBS buffer and the smoothest shape was obtained at $\mathrm{pH} 8$ (Figure 5).

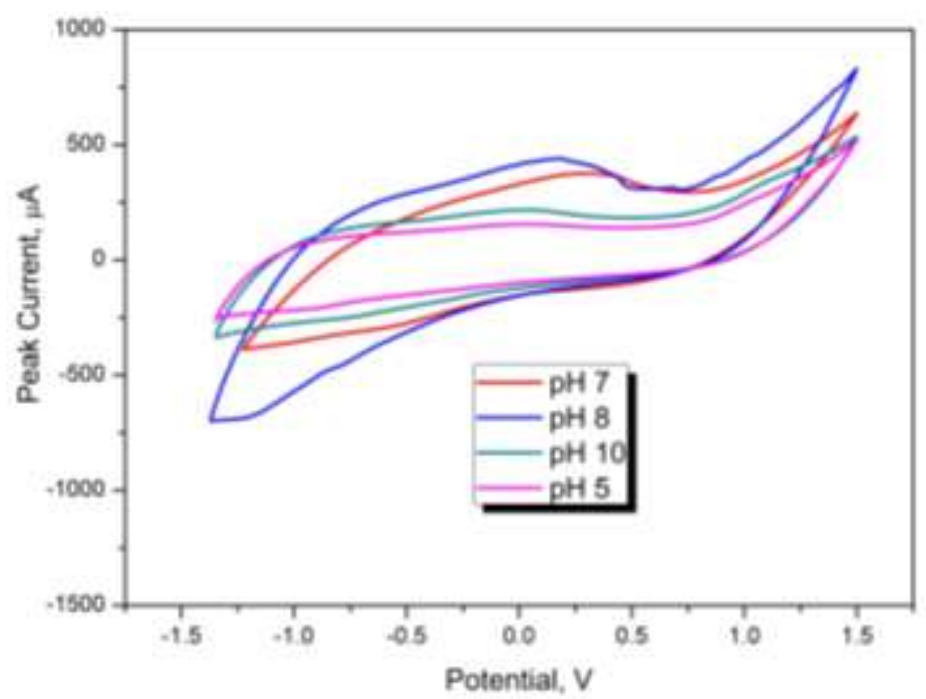

Figure 5. CVs of $1 \mathrm{mM}$ propranolol in the $\mathrm{pH} 5.0-10.0$ range PBS, scan rate: $50 \mathrm{mV} \mathrm{s}^{-1}$

The $\mathrm{pH}$ of the solution increased from 7.0 to 8.0 and the peak potential shifted to negative potential, therefore it was found that the electrochemical reaction of propranolol also included the transfer of protons.

The CVs of the rGO/SPCE electrodes were taken at different scan rates in $1 \mathrm{mM} \mathrm{pH} 8.0$ PBS. The CVs obtained for each electrode are given in Figure 6. Furthermore, the graphs of the anodic peak currents were plotted against the square root of the scan rate (Figure 7). It can be seen from the CVs that the anodic peak currents increase as the scan rate increases. This increase in the anodic peak currents is linear with the square root of the scan rate. According to these results, the electrochemical process formed by the oxidation of propranolol in the $\mathrm{rGO} / \mathrm{SPCE}$ electrode is diffusion controlled. 


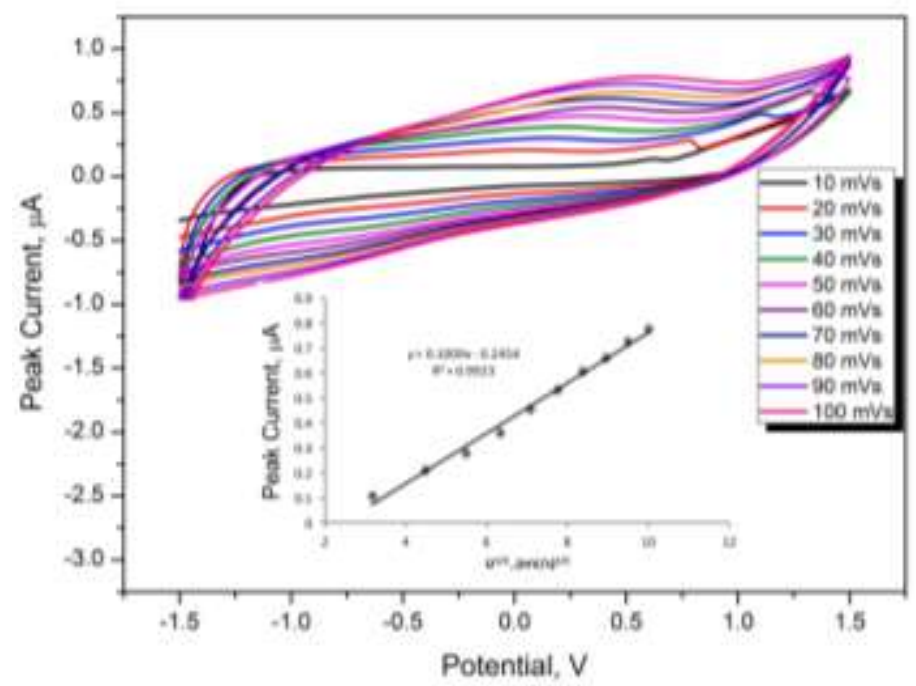

Figure 6. $\mathrm{CVs}$ of $\mathrm{rGO} / \mathrm{SPCE}$ electrode in the range of $-1.5 \mathrm{~V}$ to $+1.5 \mathrm{~V}$ potential, scan rate: $10-100 \mathrm{mVs}^{-1}, 1 \mathrm{mM}^{-1}$ propranolol $\mathrm{pH}$ 8.0 $\mathrm{PBS}$, inset graph: square root of peak current-scan rate from $\mathrm{CVs}$

Through the DPV voltammetric techniques, the detection limits can be reduced to very low levels. As a result of advantages such as no separation process for analysis and also the fact that the analysis is conducted in a short time, solutions containing propranolol were prepared in order to generate the calibration graph. This technique was used to plot the peak currents for the propranolol-containing solutions in the range of $0.005 \mathrm{~s}$ pulse width and $00.5 \mathrm{~V}$ amplitude [16]. The optimum operating range was determined up to $50 \mu \mathrm{M}$ and the corresponding graph is shown in Figure 7. The calibration graph equation was obtained as follows: $\boldsymbol{I} \boldsymbol{p}=\mathbf{0 . 3 0 2 7} \boldsymbol{C}_{\text {propranolol }}+\mathbf{3 6 . 2 5 9}$ and 0.9922 with correlation coefficient (Figure 8). With this technique, parameters such as limit of quantification, limit of detection and sensitivity for analytical characterization of the $\mathrm{rGO} / \mathrm{SPCE}$ electrode were determined (Table 1).
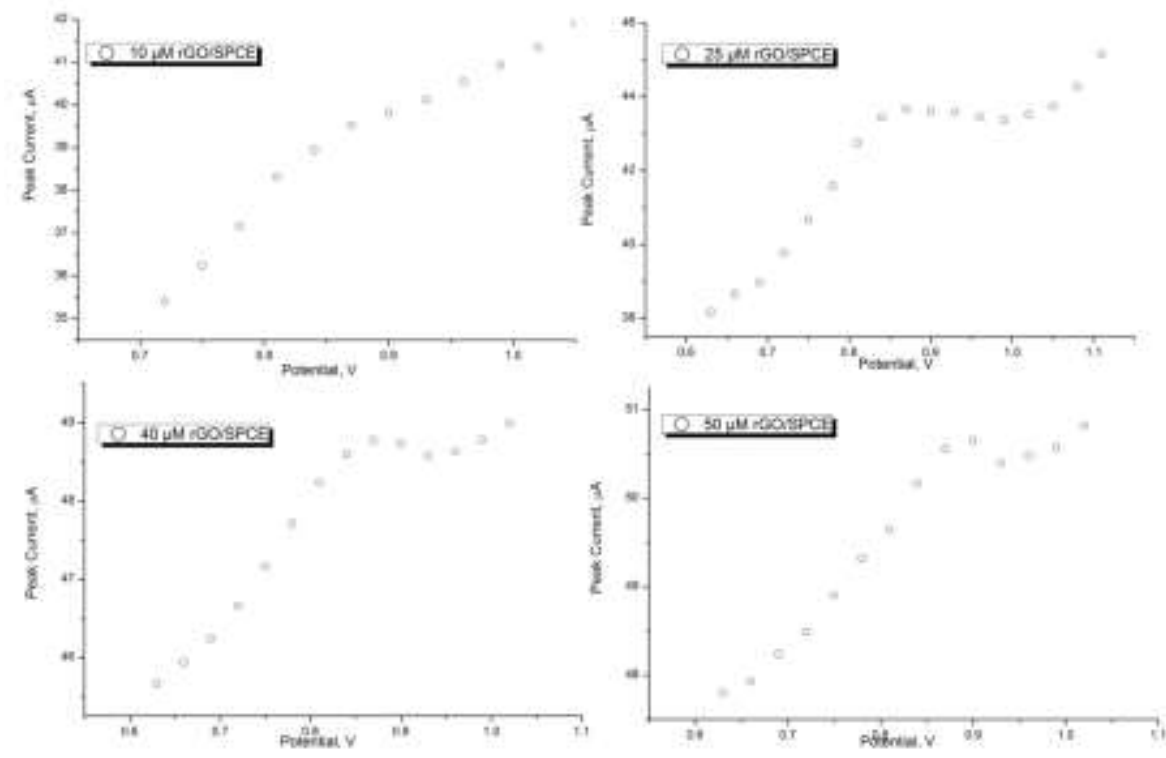

Figure 7. Anodic oxidation curves recorded in $\mathrm{rGO} / \mathrm{SPCE}$ at different analyte concentrations of propranolol in potassium buffer, $\mathrm{pH}=8 \mathrm{PBS}$, pulse amplitude: $50 \mathrm{mV}$; scan rate: $50 \mathrm{mV} / \mathrm{s}$ 


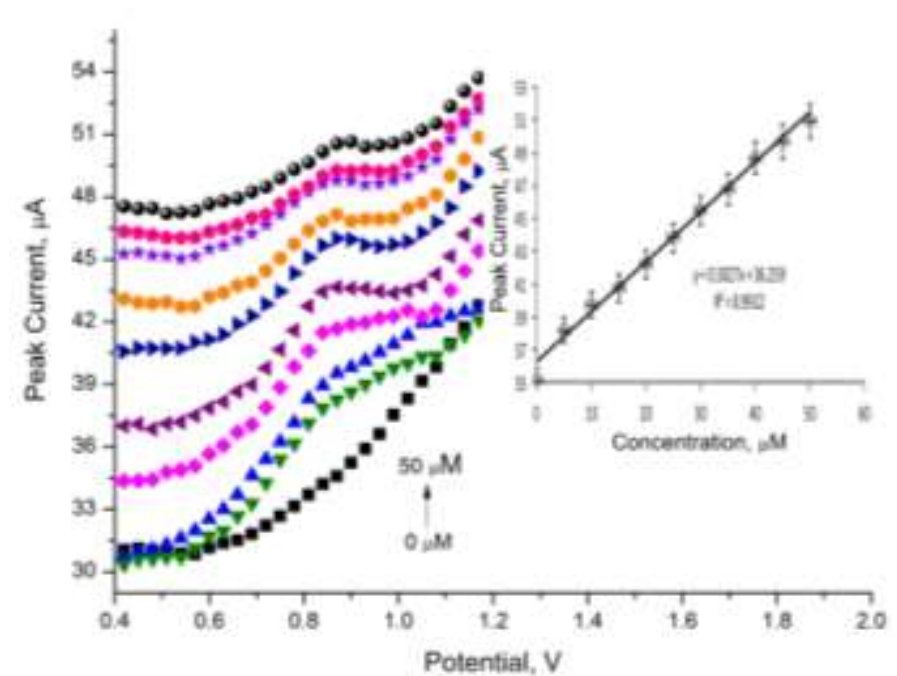

Figure 8. Anodic oxidation curves recorded in $\mathrm{rGO} / \mathrm{SPCE}$ at different analyte concentrations of propranolol in potassium buffer ( $\mathrm{pH}=8 \mathrm{PBS}$ ), (pulse amplitude: $50 \mathrm{mV}$; scan rate: $50 \mathrm{mV} / \mathrm{s}$ ): inset graph: Calibration graph obtained by DPV technique for propranolol

Table 1. Analytical parameters obtained from the rGO/SPCE electrode for the determination of propranolol by DPV

\begin{tabular}{ll}
\hline Limit of Detection & $2.61 \mu \mathrm{M}$ \\
\hline Limit of Quantification & $8.72 \mu \mathrm{M}$ \\
\hline Linear Range & $5-50 \mu \mathrm{M}$ \\
\hline Sensitivity & $4263.38 \mu \mathrm{AmM}^{-1} \mathrm{~cm}^{-2}$ \\
\hline
\end{tabular}

As seen in Table 1, the sensitivity of the rGO/SPCE electrode is quite high. This is due to the rapid transfer of electrons, with the increase of the electroactive surface area and electronic conductivity. The limit of detection and the limit of quantification can be calculated by the following equation based on the standard deviation and slope:

$$
\begin{aligned}
& \text { LOD }=\frac{3 * s_{\mathbf{y} / \mathbf{x}}}{\mathbf{m}} \\
& \text { LOQ }=3 *\left(\frac{3 * \mathbf{s}_{\mathrm{y} / \mathrm{x}}}{\mathbf{m}}\right)
\end{aligned}
$$

Where $\mathbf{s}_{\mathbf{y} / \mathbf{x}}$ is the standard error of the graph and $\mathrm{m}$ is the slope of the calibration graph [17]. The calibration graph was drawn with optimum working conditions and the $\mathbf{y}=\mathbf{a x}+\mathbf{b}$ equation was obtained. Standard error of the calibration graph can be calculated by the following equation:

$$
\mathbf{s}_{\mathrm{y} / \mathbf{x}}=\sqrt{\frac{\sum_{\mathrm{i}=\mathbf{1}}^{\mathrm{N}}(\mathrm{yi}-\hat{\mathbf{y}})^{2}}{\mathrm{~N}-2}}
$$

\section{Conclusion and Recommendations}

In this study, a new electrochemical sensor for propranolol analysis was developed with rGO/SPCE. The kinetic studies of propranolol were performed with $\mathrm{CV}$ at a scan rate of $10-100 \mathrm{mVs}^{-1}$ in $0.1 \mathrm{M} \mathrm{pH}$ 8 PBS. The propranolol oxidation mechanism was irreversible and diffusion controlled. After optimizing the best operating conditions of the developed sensor ( $\mathrm{pH}$, voltage, scanning speed, etc.), the most important analytical performance values of a sensor, the limit of detection and the limit of quantification, the linear concentration range and the sensitivity properties were examined. The propranolol linear concentration range was found as 5- $50 \mu \mathrm{M}$, the detection and quantification limits were $2.61 \mu \mathrm{M}$ and $8.72 \mu \mathrm{M}$, and the sensitivity of the sensor was $4263.38 \mu \mathrm{A} / \mathrm{mMcm}^{2}$, respectively. 
This study proposes an easy and cost-effective sensor structure for the selective determination of propranolol. The low detection limit (low micromolar) is very useful in making simple devices for the detection of propranolol in pharmaceutical preparations.

\section{Author's Contributions}

Concept, design, resources, data collection and/or processing, analysis, literature search and writing manuscript - H.Ç.K

\section{Statement of Conflicts of Interest}

No potential conflict of interest was reported by the author.

\section{Statement of Research and Publication Ethics}

The author declares that this study complies with Research and Publication Ethics.

\section{References}

[1] Moscou K., Snipe K. 2013. Pharmacology for Pharmacy Technicians. Elsevier, Missouri, 354357.

[2] Vázquez P., Martínez Galera M., Serrano Guirado A. 2010. Determination of five beta-blockers in wastewaters by coupled-column liquid chromatography and fluorescence detection. Analytica Chimica Acta, 666: 38-44.

[3] Sendon J.L., Swedberg K., McMurray J., Tamargo J., Maggioni A.P., Dargie H. 2004. Expert consensus document on beta-adrenergic receptor blockers, Europen Society of Cardiology, 25: 1341-1362.

[4] Frishman W.H. 2008. Beta-adrenergic blockers: a 50-year historical perspective. American Journal of Therapeutics, 15: 565-76.

[5] Santoro M.I.R.M., Cho H.S., Kedor-Hachman E.R.M. 1996. Simple template-free solution route for the synthesis of $\mathrm{Cu}(\mathrm{OH})_{2}$ and $\mathrm{CuO}$ nanostructures and application for electrochemical determination three ß-blockers. Analytical Letters, 29: 775.

[6] Siren H., Saarinen M., Hainari S., Riekkola M.L. 1993. Screening of beta-blockers in human serum by ion-pair chromatography and their identification as methyl or acetyl derivatives by gas chromatography-mass spectrometry. Journal of Chromatography A, 632:215.

[7] Clohs L., McErlane K.M. 2003. Comparison between capillary electrophoresis and highperformance liquid chromatography for the stereoselective analysis of carvedilol in serum. Journal of Pharmaceutical and Biomedical Analysis, 31: 407.

[8] Modamio P., Lastra C.F., Marino E.L. 1998. Error structure for the HPLC analysis for atenolol, metoprolol and propranolol: a useful weighting method in parameter estimation. Journal of Pharmaceutical and Biomedical Analysis, 17: 507.

[9] Nasrin S., Mohammad H., Lotfali S., Robab M., Abolghasem J. 2011. Electrochemical behavior of atenolol, carvedilol and propranolol on copper-oxide nanoparticles. Electrochimica Acta, 58: 336-347.

[10] Kazici H.C, Yayla M, Ulaş B, Aktaş N, Kivrak H. 2019. Development of Nonenzymatic Benzoic Acid Detection on PdSn/GCE/Vulcan XC-72R Prepared via Polyol Method. Electroanalysis, 31: 1118-1124.

[11] Kazici H.C, Salman F., Kivrak H.D. 2017. Synthesis of Pd-Ni/C bimetallic materials and their application in non-enzymatic hydrogen peroxide detection. Materials Science-Poland, 35: 660666.

[12] Nassef H.M., Civit L., Fragoso A., Sullivian C.K. 2008. Amperometric sensing of ascorbic acid using a disposible screen-printed electrode modified with electrografted o-aminophenol film. Analyst, 133: 1736-1741.

[14] Mccreey R.L. 2008. Advanced Carbon Electrode Materials for Molecular Electrochemistry. Chem. Rev., 108: 2646-2687. 
[15] Serafin V., Agul L., Yanez-Sedeno P., Pingarron J.M. 2011. A novel hybrid platform for the preparation of disposable enzyme biosensors based on poly(3,4-ethylenedioxythiophene) electrodeposition in an ionic liquid medium onto gold nanoparticles-modified screen-printed electrodes. Journal of Electroanal Chem., 656: 152-158.

[16] Olson M.P., Lacourse W.R. 2004. Voltammetry. In: Ewing's Analytical Instrumentation Handbook, Ed.: Cazes, J., 3rd Ed. Boca Raton FL: CRC Press, 529-544.

[17] Greef R.G., Peat R., Peter L.M., Pletcher D., Robinson J. 1990. Instrumental Methods in Electro Chemistry. London, Ellis Horwood series in Physical Chemistry.

[18] Kazici H.C. 2018. The Ultra-sensitive method development using Nafion and multi-walled carbon nanotube coated glassy carbon electrode for atenolol determination. Pamukkale University Journal of Engineering Sciences, 24: 1287-1292. 